\title{
Incidental cerebellar dermoid cyst mimicking low grade glioma in a teenager
}

\author{
Sharon Wulfovich, ${ }^{1}$ Suzanne Tucker, ${ }^{2}$ Michael Levy, ${ }^{3}$ John Ross Crawford ${ }^{4}$
}

'Department of Neurosciences, University of California San Diego Health Sciences, San Diego, California, USA

2Department of Pathology, Rady Children's Hospital, San Diego,

California, USA

${ }^{3}$ Neurosurgery, University of California, San Diego, California, USA

${ }^{4}$ Neurosciences and Pediatrics, Diego, La Jolla, California, USA

\section{Correspondence to}

Dr John Ross Crawford; jrcrawford@ucsd.edu

Accepted 12 February 2021 University of California San

\section{DESCRIPTION}

A 16-year-old boy with no significant medical history or family history sustained a concussion after an altercation. CT revealed an incidental finding of a heavily mineralised left inferior paramedian cerebellar lesion demonstrating cystic components (figure 1A). MRI revealed minimal peripheral enhancement and no evidence of reduced diffusivity (figure 1B-C). Differential diagnosis included juvenile pilocytic astrocytoma, postinfectious or postinflammatory process, cavernoma or other vascular malformations with encephalomalacia. Although the patient did not have any symptoms prior to the trauma, after the incident he started having frequent headaches, dizziness, trouble concentrating and anxiety. He denied any visual problems, back pain or any problems with gait or balance. Physical examination was significant for slightly slowed bilateral rapid alternating movements without dysmetria or tremor. Due to symptom onset coinciding with trauma, the patient was treated at a concussion clinic and was prescribed symptomatic treatment for his headaches. The headaches did not improve after 3 months of therapy and an MRI was repeated that showed a stable lesion. Due to the lack of symptomatic improvement, the patient and family wanted to proceed with surgery as opposed to observation where a gross total resection of the posterior fossa mass was achieved. Tissue pathology (figure 2) showed a cystic space lined by squamous epithelium with abundant calcifications, several fragments of embedded hair material, numerous cholesterol clefts, giant cells and hemosiderin-laden macrophages. Adjacent cerebellar tissue with gliosis, including Rosenthal fibres, was identified. These findings were most consistent with a diagnosis of a dermoid cyst. The patient's symptoms resolved several months following surgical resection.

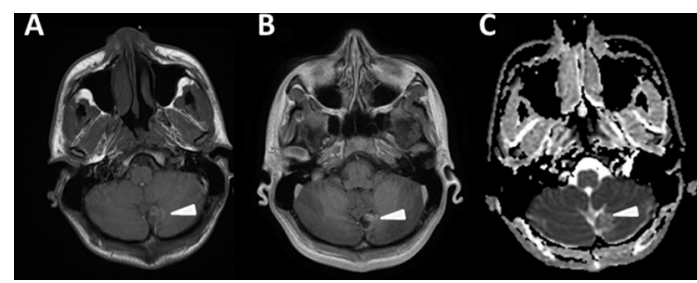

Limited 2021. No commercial re-use. See rights and permissions. Published by BMJ.

To cite: Wulfovich $S$ Tucker $\mathrm{S}$, Levy M, et al. BMJ Case Rep 2021;14:e241227. doi:10.1136/bcr-2020241227

Figure 1 Neuroimaging findings of cerebellar dermoid cyst. $\mathrm{CT}$ revealed an incidental finding of a heavily mineralised left inferior paramedian cerebellar lesion demonstrating cystic components (A). MRI revealed minimal peripheral enhancement and no evidence of

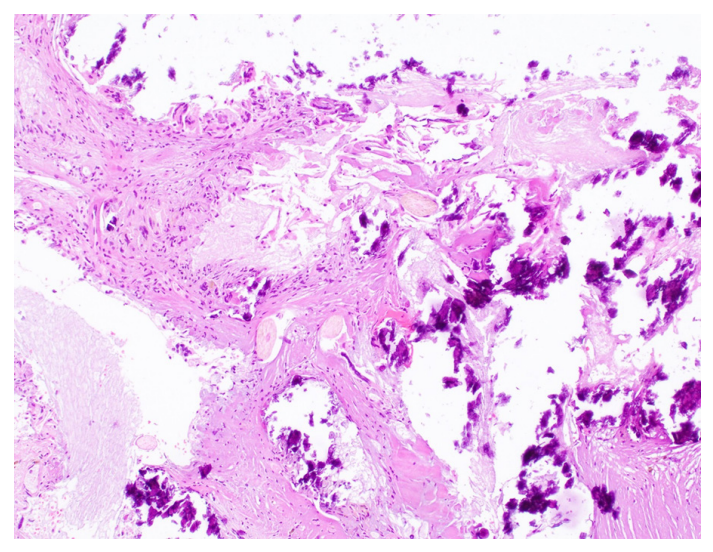

Figure 2 Histological features of cerebellar dermoid cyst. Neuropathology showed a cystic space lined by squamous epithelium. Much of the cyst wall epithelium was denuded and replaced with foreign body giant cell reaction with abundant calcifications. Numerous cholesterol clefts, giant cells and hemosiderin-laden macrophages were identified. There are multiple foci of basophilic calcifications, some of which are undergoing ossification. Several fragments of hair material are embedded within and adjacent to the cyst. Adjacent cerebellar tissue has gliosis, including Rosenthal fibres.

Intracranial dermoid cysts are extremely rare and congenital benign tumours encompassing less than $1 \%$ of all intracranial tumours. ${ }^{1}$ As they arise from ectodermal committed cells, histologically, dermoid cysts are lined by stratified squamous epithelial cells and may contain calcifications, sebaceous and sweat glands' secretions, desquamated epithelium and hair follicles. They most frequently occur in the posterior fossa and are typically present with mass effect symptoms. MRI usually shows T1 hyperintensity due to the fat content and variable signal on T2. Contrastingly to dermoid cysts, calcifications in pilocytic astrocytoma are uncommon. ${ }^{2}$

Rupture of intracranial dermoid cysts has been reported after closed head injury. ${ }^{3}$ Large ruptures

\section{Learning points}

- Intracranial dermoid cysts are extremely rare benign tumours that should be included in the differential diagnosis of calcified posterior fossa masses. reduced diffusivity $(\mathrm{B}-\mathrm{C})$. 
produce MRI findings with high-intensity signal on T1-weighted images. An analysis of 44 adult cases found that the most common symptoms associated with ruptured dermoid cysts are headaches $(31.8 \%)$, seizure $(29.5 \%)$ and temporary sensorimotor symptoms (15.9\%). Headaches were experienced more often in younger adult patients in association with dermoid cysts. ${ }^{4}$ Recurrence rates depend on the degree of resection (total vs near-total), a study of 33 patients with intracranial dermoid and epidermoid tumours found a recurrence rate of $9 \%$ in gross total resection $(n=3) .^{5}$

Our case highlights that intracranial dermoid cysts may mimic findings of cystic calcified low grade glioma on neuroimaging and should be included in the differential diagnosis of calcified posterior fossa tumours.

Contributors Ms SW, Dr ST, Dr ML and Dr JRC were responsible for the design and writing of the manuscript.
Funding The authors have not declared a specific grant for this research from any funding agency in the public, commercial or not-for-profit sectors.

Competing interests None declared.

Patient consent for publication Obtained.

Provenance and peer review Not commissioned; externally peer reviewed.

\section{REFERENCES}

1 El-Bahy K, Kotb A, Galal A, et al. Ruptured intracranial dermoid cysts. Acta Neurochir 2006;148:457-62.

2 Chourmouzi D, Papadopoulou E, Konstantinidis M, et al. Manifestations of pilocytic astrocytoma: a pictorial review. Insights Imaging 2014;5:387-402.

3 Phillips WE, Martinez CR, Cahill DW. Ruptured intracranial dermoid tumor secondary to closed head trauma. J Neuroimaging 1994;4:169-70.

4 Stendel R, Pietilä TA, Lehmann K, et al. Ruptured intracranial dermoid cysts. Surg Neurol 2002;57:391-8

5 Lynch JC, Aversa A, Pereira C, et al. Surgical strategy for intracranial dermoid and epidermoid tumors: an experience with 33 patients. Surg Neurol Int 2014;5:163.

Copyright 2021 BMJ Publishing Group. All rights reserved. For permission to reuse any of this content visit https://www.bmj.com/company/products-services/rights-and-licensing/permissions/

BMJ Case Report Fellows may re-use this article for personal use and teaching without any further permission.

Become a Fellow of BMJ Case Reports today and you can:

- Submit as many cases as you like

- Enjoy fast sympathetic peer review and rapid publication of accepted articles

- Access all the published articles

- Re-use any of the published material for personal use and teaching without further permission

\section{Customer Service}

If you have any further queries about your subscription, please contact our customer services team on +44 (0) 2071111105 or via email at support@bmj.com.

Visit casereports.bmj.com for more articles like this and to become a Fellow 